\title{
Surtos de tripanossomose bovina em rebanhos leiteiros do estado de Minas Gerais
}

Rodrigo Melo Meneses', Layanne Duarte Ferreira, Anna Luiza Belli de Souza Alves Costa, João Paulo Andrade, Isabela Oliveira Melo, Leandro Silva de Andrade, Antônio Último de Carvalho, Elias Jorge Facury Filho

Departamento de Clínica e Cirurgia Veterinárias, Escola de Veterinária, Universidade Federal de Minas Gerais (UFMG), Belo Horizonte, MG, Brasil

*Autor correspondente

e-mail: menesesrm@gmail.com

\section{Resumo}

Trypanosoma vivax é o principal agente da tripanossomose em bovinos e gera grande impacto econômico na África e América Latina. Nas Américas, o parasito é transmitido mecanicamente por insetos hematófagos e fômites. Recentemente, surtos têm sido relatados em diversos estados do Brasil, causando redução da produção, abortos e mortes. Diante disso, objetivou-se relatar a ocorrência de surtos de tripanossomose bovina em rebanhos leiteiros de Minas Gerais. Cinco rebanhos bovinos de produção de leite da região Central Mineira foram visitados entre outubro de 2014 e junho de 2015, nos quais as principais queixas dos proprietários consistiam em queda na produção de leite e emagrecimento dos animais. Nas propriedades, obteve-se o histórico da doença e amostras aleatórias de sangue de bovinos de diferentes categorias foram coletadas em tubos contendo EDTA, sendo posteriormente analisadas pela técnica de Woo. Em todas as propriedades, vacas em lactação foram diagnosticadas com Trypanosoma spp., com frequência de animais positivos variando de 10,3 a 81,3\%. Entre 6,4 e 37,7\% das vacas em lactação apresentaram-se anêmicas (VG $<24 \%$ ). Dois rebanhos apresentaram animais positivos no lote de vacas secas e em um deles bezerras também mostraram-se infectadas. Em todas as propriedades os animais eram mestiços Holandês x Zebu e ocitocina era administrada durante a ordenha, com o compartilhamento de agulhas e seringas. Em três rebanhos havia tido compra de animais em menos de seis meses, sendo o proprietário de um deles comerciante de gado. Em um outro, três vacas da fazenda vizinha foram ordenhadas na propriedade havia 30 dias e o último recebeu animais de devolução após a venda. Nas propriedades, a doença teve início entre 15 dias e seis meses antes da visita. A morbidade das vacas em lactação, de acordo com os proprietários, variou entre 7,5 e 36,5\% e a mortalidade entre 0,5 e 17,6\%. Em quatro rebanhos, os proprietários relataram ter tratado os animais mais acometidos com diaceturato de diminazeno, além de antibacterianos. Os principais 
sinais descritos pelos proprietários foram mucosas pálidas e amarelas, redução do consumo de alimentos, emagrecimento, bambeira, cegueira, aborto, febre, lacrimejamento, cansaço e redução da produção, os quais eram condizentes com os achados clínicos observados no dia das visitas. Houve redução da produtividade variando entre 16,7 e 55\% em três rebanhos. Nos demais, redução na produção de leite diária do rebanho não foi relatada, apenas dos animais doentes. A entrada de animais nas propriedades e o uso compartilhado de agulhas e seringas para a administração de ocitocina possivelmente foram os principais responsáveis pela disseminação da tripanossomose nos rebanhos visitados. Dessa forma, os surtos desencadearam principalmente redução da produção de leite, além de altas taxas de morbidade e mortalidade. 